\title{
Pengaruh Pendidikan Tinggi, Kepadatan Penduduk, Mortalitas Bayi, dan PDB Per-Kapita Terhadap Tingkat Fertilitas di Indonesia
}

\author{
Paskasius Kletus Aprila Severus ${ }^{1}$ \\ ${ }^{1}$ Departemen Ilmu Ekonomi, Universitas Airlangga, Surabaya \\ 1paskasius.aprilaseverus@gmail.com
}

\begin{abstract}
The goal of this research is to see whether higher education, population density, infant mortality and GDP per capita has impact on fertility in Indonesia or not. This study used estimates of Vector Error Correction Model (VECM) where the estimated VECM simultaneously contained the analysis of changes in the short term, and also long term. The study also includes granger causality test. Then to estimate the large contribution of independent variables in influencing the dependent variable, variance decomposition test was also included. The results showed there were three independent variables that had a significant influence, including the participation of higher education, population density, and GDP per capita in the long run, while the infant mortality rate did not affect the changes in fertility rates.
\end{abstract}

Keywords:Fertility, demographic transition, education, population density, GDP.

\section{Pendahuluan}

Perubahan yang terjadi pada sebuah negara dapat dipengaruhi oleh intervensi dan kebijakan-kebijakan yang dijalankan oleh pemerintah. Kebijakan pemerintah kemudian mendorong terjadinya transisi-transisi pada sektor perekonomian. Diantaranya transisi demografi, modal manusia dan kinerja ekonomi. Dalam penelitian ini, analisis lebih ditekankan untuk mengamati bagaimana variabel yang digunakan dalam penelitian yakni pendidikan tinggi, kepadatan penduduk, tingkat mortalitas bayi, dan PDB per kapita mempengaruhi perubahan yang terjadi pada tingkat fertilitas sebagai indikator transisi demografi yang timbul oleh karena intervensi atau kebijakan yang dijalankan oleh pemerintah.

Perubahan yang terjadi pada tingkat fertilitas dari suatu masa ke masa berikutnya dimana kemudian mempengaruhi perubahan demografi pada sebuah negara, pada jangka panjang perubahan yang terjadi pada tingkat fertilitas dapat dikatakan juga sebagai transisi demografi. Transisi demografi dinilai sebagai faktor yang dapat mempengaruhi pertumbuhan ekonomi (Frini dan Muller, 2012).

Pergerakan fertilitas pada sebuah titik menuju titik yang lain merupakan salah satu faktor terjadinya transisi demografi, tentu hal ini dikarenakan terjadinya perubahan pada fertilitas yang diakibatkan oleh beberapa hal. Terdapat banyak faktor dalam menjelaskan terjadinya pergerakan fertilitas, termasuk perubahan keterampilan teknis yang bias, penurunan biaya kontrasepsi, peningkatan upah relatif perempuan, peningkatan harapan hidup, dan penurunan nilai tenaga kerja anak (Aaronson, dkk: 2011).

Intervensi pemerintah sebagai kontrol tingkat fertilitas dan menekan angaka mortalitas bayi merupakan wujud dari perhatian terhadap kualitas hidup masyarakat didalamnya, tak jarang pula pemerintah menunjang program-programnya melalui instansi terkait untuk mendorong kesadaran masyarakat akan pentingnya mengontrol pertumbuhan penduduk. Padatnya penduduk secara psikologis dapat mempengaruhi seseorang untuk mengontrol tingkat kelahiran. Fenomena yang terjadi terkait dengan kepadatan penduduk, membentuk sebuah pola pikir dan prefrensi masyarakat dalam menentukan jumlah anak atau kualitas pendidikan dan pengetahuan anak.

Perubahan tingkat fertilitas dilihat melalui kinerja perekonomian, Liebenstein dalam jurnal Frini dan Muller (2012) mengungkapkan sebagaimana perubahan sosial-ekonomi menimbulkan sebuah pemikiran bahwa tingkat kepuasan akan menambah jumlah anak akan meningkat secara statis sementara keuntungan secara ekonomi akan berkurang, dengan biaya

DOI: 10.33603/ejpe.v7i2.2307

This is an open access article under the CC-BY-SA license 
yang dikeluarkan akan semakin besar seiring meningkatnya keinginan untuk menambah jumlah anak. Stigma masyarakat konvensional mengenai keuntungan ekonomi dalam menambah jumlah anak yang dimiliki berubah seiring dengan berkembangnya zaman, dimana orang lebih memiliki prefrensi dalam melakukan konsumsinya. Manusia modern akan lebih memilih melakukan investasi pada barang mewah, serta meningkatkan kemampuan atau skill yang dimiliki untuk persiapan di masa depan dalam menghadapi perubahan yang terjadi seiring bertambahnya waktu.

Sebagaimana tingkat fertilitas merupakan variabel yang dipengaruhi, kemudian pendidikan tinggi, kepadatan penduduk, mortalitas bayi dan PDB per kapita merupakan variabel bebas, maka penelitian ini memiliki tujuan untuk melihat hubungan jangka panjang yang terjadi. Jika terjadi perubahan pada tingkat fertilitas maka penelitian ini sekaligus dapat melihat bagaimana dan seberapa besar peran variabel bebas dalam mempengaruhi tingkat fertilitas.

Dengan menggunakan data time series, diharapkan agar penelitian ini dapat ditemukan pola yang mempengaruhi tingkat fertilitas sebagai salah satu faktor yang mempengaruhi perubahan atau transisi demografi di Indonesia. Data dengan observasi 40 tahun diperoleh dari World Bank, dengan harapan dapat memperoleh hasil intepretasi yang baik dan sesuai dengan kondisi di Indonesia.

Dalam kasus transisi demografi fertilitas dan mortalitas memiliki hubungan positif, hal demikian sesuai dengan pernyataan Todaro (2003), dan Bogue (1969) yang kemudian menggambarkan teori transisi demografi dengan menggunakan grafik perubahan kependudukan dengan melalui klasifikasi perubahan. Bogue dengan lima tahap penyesuaian kependudukan dengan menunjukan tren fertilitas dan mortalitas yang dimulai pada tingkat yang tinggi, lalu tren yang menurun, dan kemudian pada tingkat yang rendah dan cenderung stabil.

Todaro membaginya dalam tiga tahap, dimana tahap pertama fertilitas dan mortalitas pada tingkat yang tinggi yang kemudian diikuti oleh mortalitas yang menurun secara perlahan, tahap kedua fertilitas menurun dengan drastis dengan mortalitas pada tingkat yang rendah dan terus menurun, hingga tahap ketiga dimana garis fertilitas sejajar dengan mortalitas dengan tingkat yang lebih tinggi dibandingkan dengan mortalitas, tetapi pertumbuhan penduduk cenderung stabil.

Pendidikan tinggi sebagai determinan fertilitas, apa yang di ungkapkan oleh Becker mengenai hubungan transisi demografi dengan modal manusia yakni terjadinya tradeoff, yang muncul karena dorongan dari sebuah intervensi dari luar maupun kebijakan yang dilakukan oleh pemerintah. Trade-off ini terjadi demikian sebagai salah satu bentuk kesadaran dan dorongan bahwa orang tua cenderung akan berinvestasi pada pendidikan anaknya daripada harus memilih untuk menambah jumlah anaknya, dewasa kini kesadaran orang-orang dewasa mengenai pendidikan kian baik sehingga banyak dari populasi pada usia dewasa akan mengenyam pendidikan yang lebih tinggi, terutama kaum wanita akan kian sadar mengenai kebutuhan pendidikan, yang kemudian secara tidak langsung wanita secara praktikal melakukan trade-off bagi waktu luangnya untuk menempuh pendidikan tinggi yang juga secara tidak langsung mempengaruhi tingkat fertilitas karena wanita cenderung menunda pernikahan dan membatasi jumlah anak yang dimiliki agar dapat bekerja.

De la Croix dan Gobbi (2016) mengatakan, jika menurut pandangan modern, pendapatan yang lebih tinggi pada daerah yang padat penduduk karena terjadinya eksternalitas aglomerasi, fertilitas akan turun oleh pendapatan, yang mengarah pada hubungan negatif yang sama antara kepadatan dan fertilitas.

p-ISSN 2337-571X | e-ISSN 2541-562X

CProdi Pendidikan Ekonomi Unswagati Cirebon 
Courgeau (1989) dalam De la Croix dan Gobbi (2016) mengatakan bahwa terdapat kecenderungan dimana keluarga yang memutuskan memiliki anak lebih sedikit akan bermigrasi menuju wilayah yang padat penduduk dan mencari dan menikmati kesempatan untuk memperoleh pendapatan yang lebih besar dan lebih baik, sebaliknya ketika sebuah keluarga memutuskan untuk memiliki jumlah anak lebih akan memilih untuk pindah pada wilayah yang tingkat kepadatannya cukup rendah dimana biaya yang diperlukan untuk membesarkan anak cenderung rendah pula.

Micevska (2001) berpendapat bahwa fertilitas, di sisi lain juga mempengaruhi pertumbuhan ekonomi; ketika jumlah anak pada setiap keluarga besar, perhatian yang diberikan pada anak oleh orang tuanya rendah, maka akan mengakibatkan menurunnya tingkat output modal manusia; namun ketika ukuran sebah keluarga kecil, kemudian tingkat kualitas modal manusia tinggi akan menghasilkan pekerja yang sangat produktif dan kemudian hal ini akan mempercepat pertumbuhan output yang dapat mempengaruhi pertumbuhan ekonomi. Demikian pula investasi yang dilakukan orang tua terhadap anaknya ketika jumlah anak yang dimiliki relatif besar maka biaya yang dikeluarkan oleh orang tua juga tentu akan semakin besar, namun ketika jumlah anggota keluarga cenderung kecil, investasi yang mungkin dapat dilakukan oleh orang tua akan dapat optimal dan anak akan memperoleh pendidikan lebih baik dan pelatihan untuk memperoleh keahlian yang dibutuhkan di kemudian hari.

\section{Metode Penelitian}

Penelitian ini menggunakan pendekatan kuantitatif, penelitian kuantitatif merupakan pendekatan yang lebih fokus menguji data-data empiris dengan menggunakan metodemetode ekonometrika untuk membuktikan sebuah hipotesis. Penelitian ini menggunakan metode ekonometrika time series yang di uji dengan menggunakan pendekatan model VECM (Vector Error Correction Model). Penelitian akan melihat hubungan antar variabel dengan menggunakan Granger causality, dan kemudian untuk melihat respon hubungan dalam jangka panjang maupun jangka pendek digunakan VECM, dengan mengestimasi hasil variance decomposition dan impulse response. Alat ekonometrika yang digunakan dalam penelitian ini adalah eviews 8 dengan menggunakan data time series selama 40 tahun dari periode 1972-2012.

Berdasarkan hasil penelitian terdahulu dan analisis model pada penelitian ini variabel diklasifikasikan dalam dua jenis variabel yakni fertilitas sebagai variabel terikat (dependent variable) dan partisipasi pendidikan tinggi, kepadatan penduduk, mortalitas bayi, dan PDB per kapita merupakan variabel bebas (Independent variables) yang kemudian mempengaruhi variabel dependent dan memiliki sifat deterministic. Variabel-variabel tersebut merupakan indikator yang akan digunakan penelitian yang bersumber di Indonesia dalam jangka waktu 40 tahun, atau diantara lain data dari variabel tersebut berupa penelitian time series selama 40 tahun.

Analisis model di dalam penelitian ini yakni, dengan melihat perubahan-perubahan yang terjadi pada seperti pendidikan tinggi, kepadatan penduduk, mortalitas bayi, dan PDB per kapita sebagai variabel yang mepengaruhi perubahan tingkat fertilitas dengan melihat gejolak dan perubahan. Untuk menggambarkan kondisi tersebut dengan metode penelitian VECM, model dapat dituliskan dengan:

$$
\begin{array}{r}
{\left[\Delta \ln F R T_{5 t}\right]=\Gamma\left[\begin{array}{c}
\Delta \ln P T_{1 t-1} \\
\Delta \ln P E N_{2 t-1} \\
\Delta \ln M R T_{3 t-1} \\
\Delta \ln P D B_{4 t-1}
\end{array}\right]+\left[\begin{array}{l}
\alpha_{11} \\
\alpha_{21} \\
\alpha_{31} \\
\alpha_{41}
\end{array}\right] \chi\left[\beta_{11} \beta_{21} \beta_{31} \beta_{41}\right] \chi\left[\begin{array}{c}
\ln P T_{1 t-1} \\
\ln P E N_{2 t-1} \\
\ln M R T_{3 t-1} \\
\ln P D B_{4 t-1}
\end{array}\right] \ldots \ldots \ldots \ldots .(1)} \\
\text { P-ISSN } \underline{2337-571 X} \text { | e-ISSN } \underline{2541-562 X} \\
\text { CProdi Pendidikan Ekonomi Unswagati Cirebon }
\end{array}
$$


Dimana:

$\operatorname{lnFRT}_{t}=$ Tingkat fertilitas pada periode $\mathrm{t}$

${\ln P T_{t}}_{t}=$ Tingkat partisipasi pendidikan tinggi pada periode $\mathrm{t}_{\mathrm{t}}$

${\ln P E N_{t}}=$ Kepadatan penduduk setelah lahir pada periode $_{\mathrm{t}}$

${\ln M R T_{t}}_{t}=$ Tingkat mortalitas bayi pada periode $\mathrm{t}$

$\ln P D B_{t}=$ Tingkat PDB per Kapita pada periode $_{\mathrm{t}}$

$\Gamma_{t} \quad=$ Koefisien matriks (pxp): $\mathrm{j}=1, \ldots \mathrm{K}$

$\alpha, \beta=$ Jumlah kombinasi linier elemen $\mathrm{X}$, yang dipengaruhi shock transistor.

\section{Hipotesis}

Melalui uraian pendahuluan, maka hipotesis awal penelitian ini adalah,

1. Terdapat pengaruh dari variabel tingkat pendidikan tinggi, kepadatan penduduk, tingkat kematian bayi dan PDB per kapita terhadap tingkat fertilitas

2. Pengaruh yang besar timbul dari tingkat pendidikan tinggi, kepadatan penduduk, tingkat kematian bayi dan PDB per kapita terhadap tingkat fertilitas.

3. Terdapat hubungan kausalitas antara variabel tingkat pendidikan tinggi, kepadatan penduduk, tingkat kematian bayi dan PDB per kapita terhadap tingkat fertilitas.

\section{Hasil dan Pembahasan}

Estimasi VECM

Tabel 1. Hasil Estimasi VECM Jangka Panjang

\begin{tabular}{cr}
\hline Cointegrating Eq: & CointEq1 \\
\hline FRT(-1) & 1,000000 \\
\hline PT(-1) & 0,134748 \\
\cline { 2 - 2 } & $(0,01421)$ \\
\hline PEN(-1) & {$[9,48253]$} \\
\hline & 2,330156 \\
\hline MRT(-1) & $(0,38385)$ \\
\hline & {$[6,07055]$} \\
\hline PDB(-1) & $-0,511852$ \\
\hline & {$[0,25563)$} \\
\hline C & $0,23760230]$ \\
\hline
\end{tabular}

Sumber: Olahan data 2019

Mengacu pada hasil estimasi VECM, mengatakan bahwa partisipasi pendidikan tinggi (PT) memiliki pengaruhi signifikan terhadap tingkat fertilitas di Indonesia sebesar 9,48253 dengan koefisien positif, yang memiliki arti pertumbuhan variabel PT berbalik dengan pertumbuhan variabel FRT. Pendekatan tren dalam Gambar 4.12 memberi pembuktian seiring dengan bertambahnya partisipasi pendidikan tinggi pertumbuhan daripada tingkat fertilitas menurun. Frini dan Muller (2012) biaya untuk menambah anak dapat dipengaruhi oleh pengeluaran yang dibutuhkan untuk meningkatkan kualitas modal manusia (kesehatan dan pendidikan).

Dari hasil estimasi VECM pada Tabel 1 maka dapat diperoleh hasil yakni, dari 4 variabel bebas terdapat 3 variabel yang memiliki pengaruhi signifikan, dengan 
membandingkan hasil t-statistik dengan t-tabel, dimana t-tabel memiliki nilai 2,021. Dari hasil estimasi VECM, maka persamaan yang dapat dituliskan yakni sebagai berikut:

FRT $_{\mathrm{t}-1}=-12,84100+0,134748 \mathrm{PT}_{\mathrm{t}-1}+2,330156$ PEN $_{\mathrm{t}-1}-0,511852$ MRT $_{\mathrm{t}-1}+0,237646$ PDBR $_{\mathrm{t}-1}$........(2)

Melihat hasil estimasi VECM pengaruh kepadatan penduduk (PEN) terhadap fertilitas rupanya memiliki kesesuaian dengan trend perubahan yang terjadi di Indonesia menurut data. Estimasi VECM menunjukan bahwa variabel PEN memiliki pengaruh yang signifikan terhadap FRT dimana memiliki nilai koefisien 6,07055 dan bersifat positif yakni sama dengan variabel PT. Dalam penelitiannya De la Croix dan Gobbi (2016) mengatakan, pendapatan yang lebih tinggi pada daerah yang padat penduduk karena terjadinya eksternalitas aglomerasi, fertilitas akan turun oleh pendapatan, yang mengarah pada hubungan negatif yang sama antara kepadatan dan fertilitas. Courgeau (1989) dalam De la Croix dan Gobbi (2016) mengatakan bahwa terdapat kecenderungan dimana keluarga yang memutuskan memiliki anak lebih sedikit akan ber-migrasi menuju wilayah yang padat penduduk untuk mencari dan menikmati kesempatan untuk memperoleh pendapatan yang lebih besar dan lebih baik, sebaliknya ketika sebuah keluarga memutuskan untuk memiliki jumlah anak lebih akan memilih untuk pindah pada wilayah yang tingkat kepadatannya cukup rendah dimana biaya yang diperlukan untuk membesarkan anak cenderung rendah.

Menurut hasil estimasi VECM, hubungan yang terjadi pada kedua variabel terkait yakni tingkat mortalitas bayi (MRT) dengan tingkat fertilitas (FRT), dapat disimpulkan bahwa MRT tidak memiliki pengaruh yang signifikan terhadap perubahan yang terjadi pada FRT. Hubungan yang tidak signifikan diantara MRT dengan FRT dapat dipengaruhi oleh beberapa faktor diantaranya disampaikan oleh Frini dan Muller (2012) biaya untuk menambah anak dapat dipengaruhi oleh pengeluaran yang dibutuhkan untuk meningkatkan kualitas modal manusia (kesehatan dan pendidikan). Basu (2002) mengatakan Pendidikan wanita memiliki hubungan negatif dengan kesuburan wanita, bahkan setelah faktor pendidikan suami, pendapatan, pekerjaan dan sebagainya.

Tequame dan Tirivayi (2014) berbicara mengenai akses kepada pendidikan tinggi memang memiliki peran dalam menurunkan tingkat fertilitas dengan melihat dan mengukur melalui jumlah anak yang dilahirkan dan jumlah anak yang diinginkan, maka pendidikan tinggi dapat saja mempengaruhi wanita dalam memutuskan untuk memiliki anak.Melalui hasil penelitian dan estimasi VECM, hasil yang muncul menunjukan bahwa terdapat indikasi adanya pengaruh yang signifikan diantara kedua variabel yakni PDB per kapita (PDB) dan tingkat fertilitas (FRT). Hasil estimasi VECM menunjukan nilai koefisien yang positif dan memiliki nilai t-statistik 9,43540 yang tentu melampaui jumlah nilai t-tabel. Indikasi hubungan pengaruh signifikan juga ditunjukan oleh hasil dari uji kausalitas granger dimana kedua variabel saling mempengaruhi satu dengan yang lain.

Song (2013) mengatakan, demikian perlu di sadari bahwa sebuah kebijakan dapat bekerja untuk mempersiapkan pertumbuhan ekonomi di masa depan. Hal ini karena, penduduk usia produktif dan penduduk lanjut usia menjadi kekuatan demografi yang dominan, turunya tingkat fertilitas kemudian akan mengarah pada rendahnya populasi usia produktif dibandingkan dengan populasi lansia dan tingginya rasio ketergantungan.

Sebagian besar hasil dari penelitian para ahli terdahulu mengungkapkan bahwa sebenarnya memang kedua variabel ini yakni PDB dan FRT memiliki pengaruh yang signifikan, terbilang sebagai hubungan jangka panjang, sebagaimana bahwa dasar-dasar sebuah kebijakan juga ditetapkan berdasarkan hasil penelitian dengan menggunakan dua variabel ini.

p-ISSN 2337-571X | e-ISSN 2541-562X

(C)Prodi Pendidikan Ekonomi Unswagati Cirebon 
Variance Decomposition

Variance decomposition merupakan alat yang digunakan untuk melihat seberapa besar kontribusi sebuah variabel dalam mempengaruhi sebuah variabel terhadap variabel yang lain. Dalam kesempatan ini fokus hasil dari variance decomposition yakni untuk melihat seberapa besar proporsi pergerakan shock variabel PT, PEN, MRT dan PDB kepada FRT. Hasil variance decomposition, dengan variabel FRT dan PT maka dapat disimpulkan bahwa pada awal perioder pendidikan tinggi (PT) tidak banyak memberikan kontribusi, justru tingkat fertilitas (FRT) lebih banyak dipengaruhi oleh variabel itu sendiri, namun seiring dengan bertambahnya waktu pada periode kedua proporsi shock yang ditimbulkan oleh pendidikan meningkat hingga pada periode ke lima, dan pada periode keenam hingga akhir periode observvasi proporsi shock yang ditimbulkan cenderung stabil, dan shock yang timbul dibawah $20 \%$.

Kemudian pada variabel FRT dengan PEN, dapat dilihat bahwa pada awal-awal periode observasi hingga pada periode kedua kepadatan penduduk (PEN) tidak banyak memberikan kontribusi dalam perubahan yang terjadi pada tingkat fertilitas (FRT), namun pada periode ketiga muncul indikasi bahwa terjadi perubahan pada FRT yang timbul melalui proporsi shock dari variabel PEN. Proporsi shock variabel PEN, tampak terus bertambah dan memiliki kontribusi yang cukup besar dalam mempengaruhi perubahan yang terjadi pada tingkat fertilitas, hal tersebut nampak hingga akhir periode observasi menunjukan titik yang dicapai pada kisaran $25 \%$.

Dari hasil variance decomposition pada variabel FRT dengan MRT, dapat dilihat dan disimpulkan dengan demikian, kontribusi yang ditimbulkan oleh variabel tingkat mortalitas bayi (MRT) terhadap tingkat fertilitas telah terjadi pada awal periode hingga akhir periode observasi, namun proporsi shock yang ditimbulkan oleh MRT sangatlah kecil karena bearada diawah $20 \%$ dan hampir serupa dengan tingkat partisipasi pendidikan tinggi.

Berbeda dengan shock yang ditimbulkan oleh variabel PDB per kapita (PDB) terhadap tingkat fertilitas (FRT), sejak awal periode terlihat kontribusi PDB dalam perubahan yang terjadi pada FRT, meski proporsi shock terbilang kecil, namun seiring dengan bertambahnya periode proporsi shock terus meningkat, dapat dilihat peningkatan terjadi pada kisaran awal periode hingga periode ketujuh, pada periode kedelapan hingga akhir periode observasi proporsi shock yang timbul melalui PDB terus menurun perlahan, namun proporsi shock terbilang masih tinggi karena berada dikisaran $20 \%$, yang sebelumnya sempat melampaui $20 \%$ pada kisaran $22 \%$.

Maka dapat disimpulkan bahwa kedua variabel ini membentuk sebuah hubungan dimana akan memicu terjadinya trade-off dibalik hubungan ini. Seperti apa yang menjadi pernyataan dari Frini dan Muller (2012) ketika sebuah keluarga akan dihadapkan pada pilihan dalam memiliki jumlah anak yang besar atau menambah jumlah anak, atau memaksimalkan jumlah anak yang dimiliki dengan meningkatkan kualitas dari jumlah anak yang dimiliki.

Courgeau (1989) dalam De la Croix dan Gobbi (2016) mengatakan bahwa terdapat kecenderungan dimana keluarga yang memutuskan memiliki anak lebih sedikit akan bermigrasi menuju wilayah yang padat penduduk untuk mencari dan menikmati kesempatan untuk memperoleh pendapatan yang lebih besar dan lebih baik, sebaliknya ketika sebuah keluarga memutuskan untuk memiliki jumlah anak lebih akan memilih untuk pindah pada wilayah yang tingkat kepadatannya cukup rendah dimana biaya yang diperlukan untuk membesarkan anak cenderung rendah.

Tequame dan Tirivayi (2014) berbicara mengenai akses kepada pendidikan tinggi memang memiliki peran dalam menurunkan tingkat fertilitas dengan melihat dan mengukur

p-ISSN 2337-571X | e-ISSN 2541-562X

CProdi Pendidikan Ekonomi Unswagati Cirebon 
melalui jumlah anak yang dilahirkan dan jumlah anak yang diinginkan, maka pendidikan tinggi dapat saja mempengaruhi wanita dalam memutuskan untuk memiliki anak.

Song (2013) mengatakan, demikian perlu di sadari bahwa sebuah kebijakan dapat bekerja untuk mempersiapkan pertumbuhan ekonomi di masa depan. Hal ini karena, penduduk usia produktif dan penduduk lanjut usia menjadi kekuatan demografi yang dominan, turunya tingkat fertilitas kemudian akan mengarah pada rendahnya populasi usia produktif dibandingkan dengan populasi lansia dan tingginya rasio ketergantungan.

\section{Granger Causality}

Uji kausalitas granger bertujuan untuk melihat apakah terjadi suatu hubungan timbal balik antar variabel tersebut, dengan kata lain melihat arah transmisi suatu variabel terhadap variabel lainnya

Dalam meneliti hubungan kausalitas antar variabel dengan menggunakan estimasi kausalitas granger maka asumsi yang digunakan yakni:

- nilai probabilitas $<\alpha=1 \%, \alpha=5 \%, \alpha=10 \%$, tidak terjadi unit root

- nilai probabilitas $>\alpha=1 \%, \alpha=5 \%, \alpha=10 \%$, terjadi unit root

Dimana hubungan yang kemudian timbul diantara variabel PT dengan FRT yakni hubungan kausalitas searah (unidirectional causality) dengan tingkat fertilitas (FRT) memiliki peran dalam mempengaruhi variabel pendidikan tinggi (PT). Hubungan kausalitas yang timbul diantara variabel PEN dan FRT menurut estimasi kausalitas granger, membentuk hubungan kausalitas searah (unidirectional causality), lagi FRT memiliki pengaruh dalam hubungan kausalitasnya dengan kepadatan penduduk (PEN).

Hubungan kausalitas yang timbul diantara variabel MRT dengan FRT yakni hubungan kausalitas searah (unidirectional causality), dengan tingkat fertilitas (FRT) memiliki peran dalam mempengaruhi tingkat mortalitas bayi (MRT). Hubungan terakhir yang timbul diantara PDB dengan FRT menurut estimasi kausalitas granger yakni hubungan dua arah (bilateral causality). Dengan kata lain PDB per kapita (PDB) memiliki peran dalam mempengaruhi tingkat fertilitas (FRT), demikian sebaliknya.

\section{Pembuktian Hipotesis}

Dalam membuktikan hipotesis awal penelitian ini telah dilakukan beberapa langkah pemaparan pada bab ini, dengan menggunakan berbagai langkah estimasi untuk memperoleh hasil dari penilitian mengenai pengaruhi variabel partisipasi pendidikan tinggi, kepadatan penduduk, tingkat mortalitas bayi (AKB), dan PDB per kapita terhadap tingkat fertilitas di Indonesia.

Hasil estimasi VECM menunjukan bahwa dari keempat variabel bebas terdapat tiga variabel bebas yang signifikan terhadap variabel terikat, dan satu variabel bebas yang tersisa tidak memiliki pengaruh yang signifikan terhadap variabel terikat. Variabel bebas yang memiliki pengaruh signifikan bagi tingkat fertilitas diantanya terdapat partisipasi pendidikan tinggi, kepadatan penduduk, dan PDB per kapita, sedangkan variabel bebas yang tidak memiliki pengaruh signifikan yakni tingkat mortalitas bayi. Pembuktian ini berdasarkan perbandingan nilai t-statistik tiap variabel dengan t-tabel sebagai ukuran pada estimasi VECM dengan hasil partisipasi pendidikan tinggi (PT) 9,48253, kemudian kepadatan penduduk (PEN) 6,07055, lalu PDB per kapita (PDB) 9,43540 yang ketiganya memiliki nilai koefisien positif, dan terakhir diikuti dengan tingkat mortalitas bayi (MRT) 2,00230 nilai koefisien MRT yakni negatif, dengan nilai t-tabel 2,021.

Demikian untuk mengamati hubungan yang terjadi diantara tiap variabel bebas terhadap variabel terikat dapat dilihat melalui pendekatan kausalitas granger dimana terdapat tiga variabel yang membentuk hubungan searah (unidirectional causality) yakni diantaranya 
PT, PEN, dan MRT terhadap FRT, namun terdapat satu variabel yang membentuk hubungan dua arah (bilateral causality) yakni PDB terhadap FRT.

\section{Simpulan}

Dari hasil penelitian mengenai hubungan pengaruh partisipasi pendidikan tinggi, kepadatan penduduk, tingkat mortalitas bayi, dan pertumbuhan ekonomi terhadap tingkat fertilitas maka dapat diperoleh kesimpulan sebagai berikut.

Hasil estimasi VECM menunjukan indikasi tiga dari empat variabel bebas memiliki pengaruh signifikan terhadap variabel terikat yakni tingkat fertilitas, diantaranya adalah partisipasi pendidikan tinggi, kepadatan penduduk dan PDB per kapita, sedangkan tingkat mortalitas bayi tidak memiliki pengaruh yang signifikan terhadap perubahan yang terjadi pada tingkat fertilitas.

Melalui hasil variance decomposition dapat diketahui bahwa dari ketiga variabel yang memiliki pengaruh signifikan dua diantaranya memiliki kontribusi dalam mempengaruhi perubahan pada tingkat fertilitas dengan proporsi yang cukup besar nilainya yakni berada di kisaran 20\% variabel tersebut adalah kepadatan penduduk dan pertumbuhan ekonomi.

Sebagai mana hasil dari uji kausalitas dengan menggunakan pendekatan Granger Causality ditemukan bahwa hubungan kausalitas yang terjadi pada setiap variabel penelitian, diantaranya tingkat fertilitas sebagai variabel terikat dengan pendidikan tinggi, kepadatan penduduk, tingkat mortalitas bayi, dan PDB per kapita sebagai variabel bebas yakni, terdapat tiga hubungan kausalitas satu arah (unidirectional causality) dan satu hubungan kausalitas dua arah (bilateral causality). Tiga hubungan satu arah yakni diantanya hubungan pendidikan tinggi (PT) dengan tingkat fertilitas (FRT), kepadatan penduduk (PEN) dengan tingkat fertilitas (FRT), dan tingkat mortalitas bayi (MRT) dengan tingkat fertilitas (FRT)

\section{Referensi}

Arsyad, L. (2010). Ekonomi Pembangunan. Edisi Ketiga. Yogyakarta: Badan Penerbitan STIE YKPN.

Aluko, O. O., and Adeniji S. O. (2015). Exploring the Effect of Health on Economic Growth in Nigeria: A Vector Error Correction Model Approach. International Journal of Economics, Commerce and Management, III (9): 659-678.

Basu, A. M. (2002). Why does Education Lead to Lower Fertility ? A Critical Review of Some of the Possibilities. World Development, 30(10): 1779-1790.

Badan Pusat Statistik. (2013). Proyeksi Penduduk Indonesia (Indonesia Population Projection) 2010-2035. Jakarta: BPS Indonesia.

Bloom, D. E., Canning, D. and Jaypee Sevilla. (2003). The Demographic Dividend.RAND, MR-1274. California.

De la Croix, D., Paula E. Gobbi. (2016). Population Density, Fertility, and Demographic Convergence in Developing Countries. Discussion Paper 2016-3

Enders, W. (2004). Applied Econometric Time Series. Second Edition. New York: Wiley.

Federman, M. and David I. Levine.(2005). Industrialization and Infant Mortality. Center for International and Development Economics Research, Paper C05'140. Berkeley: University of California.

Fleischhauer, Kai-Joseph. (2007). A Review of Human Capital Theory: Microeconomics. Departement Economics, Paper No. 2007-01. University of St. Gallen.

p-ISSN 2337-571X | e-ISSN 2541-562X

(CProdi Pendidikan Ekonomi Unswagati Cirebon 
Frini, O. and Christophe M. (2012). Demographic Transition, Education and Economic Growth in Tunisia. Economics Systems, (36): 351-371.

Guimarães, R. R. d.. (2013). The Future of Higher Educationin BRIC Countries: A Demographic Perspective. Centre for Development and Regional Planning, 30 (2): 549-566.

Gujarati, Damodar N. (2003). Basic Econometric. Fourth Edition. New York: McGrawHill.

Gujarati, D. dan Dawn C. P. 2009. Basic Econometrics. 5th edition. New York: McGrawHill.

Gujarati, D. (2010). Ekonometrika Dasar. Terjemahan. Jakarta: Erlangga.

Ishida, R., Oguro Kazumasa, Yasuoka Masaya. 2015. Population Density, Fertility, and Childcare Services from the Perspective of a Two-Region Overlaping Generations Model. REITI Discussion Paper Series 15-E-093.

Jones, Gavin W. (2013). The Population of Southeast Asia. Asia Research Institute Working Paper Series No. 196.

Kalemli-Ozcan, S., Harl E. Ryder, and David N. Weil. (2000). Mortality Decline, Human Capital Investment, and Economic Growth. Journal of Development Economics, 62 (1): $1-23$.

Micevska, M. B. (2001). Economic Disruption, Malthusian Fertility, and Economic Growth. Disertasi tidak diterbitkan. California Claremont Graduate University.

Severus, P.K. A. (2016). Pengaruh Pendidikan Tinggi, Kepadatan Penduduk, Mortalitas Bayi, dan PDB Per Kapita Terhadap Tingkat Fertilitas di Indonesia. Surabaya: Skripsi Program Studi Ekonomi Pembangunan Universitas Airlangga.

Song, S. (2013). Demographic Changes and Economic Growth: Empirical Evidence from Asia.Illinois: Economics Departement Illinois Wesleyan University, Paper 121.

Tequame, M., and Nyasha Tirivayi. (2014). Higher Education and Fertility: Evidence From a Natural Experiment in Ethiopia. United Nations University, 2015-019.

Todaro, Michael P and Stephen C. Smith. (2003). Economic Development. Eight Edition. Essex: Pearson Education.

Vogl, T. S. (2012). Education and Health in Developing Economies. Research Program in Development Studies, No. 1453

Vogel, E. (2011). Human Capital and the Demographic Transition: Why Schooling Became Optimal.Munich Center for the Economics of Ageing, 247-2011. University of Mannheim.

World Bank. (2015). World Development Indicators 2015 (Online), (http://data.worldbank.org/indicator/SP.DYN.TFRT.IN diakses pada tanggal 19 November 2015)

(2015). World Development Indicators $2015 \quad$ (Online), (http://data.worldbank.org/indicator/SE.TER.ENRR diakses pada tanggal 19 November 2015)

(2015). World Development Indicators $2015 \quad$ (Online), (http://data.worldbank.org/indicator/EN.POP.DNST diakses pada tanggal 19 November 2015)

p-ISSN 2337-571X | e-ISSN 2541-562X

CProdi Pendidikan Ekonomi Unswagati Cirebon 
Edunomic: Jurnal Ilmiah Pendidikan Ekonomi Fakultas Keguruan dan Ilmu Pendidikan Vol. 7, No. 2, Tahun 2019

----------. (2015). World Development Indicators $2015 \quad$ (Online), (http://data.worldbank.org/indicator/SP.DYN.IMRT.IN diakses pada tanggal 19 November 2015)

--------. (2015). World Development Indicators $2015 \quad$ (Online), (http://data.worldbank.org/indicator/NY.GDP.PCAP.KD diakses pada tanggal 19 November 2015)

Xie, Yu. (2000).Demography: Past, Present, and Future. Journal of the American Statistical Association, 95 (450): 670-673.

Zuanna, Gianpiero Dalla. (2007). Social Mobility and Fertility. Demographic Research, 17 (15): $441-464$. 